\title{
Oral Adenoid/Acantholytic Squamous Cell Carcinoma: A Report of two Cases with Review of Literature
}

\author{
Nayak SD, ${ }^{1}$ Jose $M,{ }^{1}$ Sequeira J
}

\author{
${ }^{1}$ Department of Oral Pathology and Microbiology \\ ${ }^{2}$ Departmentof Oral \& Maxillofacial Surgery \\ Yenepoya Dental College \\ Mangalore, Karnataka \\ India
}

Corresponding Author

Shruti Nayak

Department of Oral Pathology and Microbiology

Yenepoya Dental College

Mangalore, Karnataka

India

E-mail: shrushenoy@rediffmail.com

Citation

Nayak SD, Jose M, Sequeira J. Oral Adenoid/Acantholytic Squamous Cell Carcinoma: A Report of two Cases with Review of Literature. Kathmandu Univ Med J 2012;39(3):83-87.

\begin{abstract}
Adenoid squamous cell carcinoma (ASCC) is an uncommon but well recognized variant of squamous cell carcinoma. It has been reported to originate in the sun exposed skin of the head and neck region. Although rare, there are cases in records which have reported within the oral cavity and nasopharynx. Histologically the lesion shows areas of conventional squamous cell carcinoma along with atypical epithelial cells forming an adenoid pattern. There are insufficient reported cases to establish likely behaviour. Here we report two additional cases of adenoid squamous cell carcinoma, one developing in the floor of mouth and another in the maxillary sinus both were reported in March 2010 in Mangalore, India.
\end{abstract}

\section{KEY WORDS}

Acantholytic squamous cell carcinoma, adenoacanthoma, adenoid squamous cell carcinoma, pseudoglandular

\section{INTRODUCTION}

Adenoid squamous cell carcinoma (ASCC), also called pseudoglandular squamous cell carcinoma, is a tumor of sun exposed skin. ${ }^{1}$ It was originally described by Lever in 1947 and was termed as adenoacanthoma. The lesion on the skin appears as elevated nodules that may show crusting, scaling or ulceration. ${ }^{2}$ Adenoid squamous cell carcinoma is commonly seen in the head and neck region. ${ }^{3}$

Adenoid squamous cell carcinoma is a rare variant of squamous cell carcinoma (SCC), and it differs in histologic features and aggressiveness., ${ }^{4,5}$ Adenoid squamous cell carcinoma is derived its name from the pseudoglandular appearance resulting from acantholysis and degeneration within the islands of SCC. But there is no evidence of glandular differentiation, secretory activity or products. ${ }^{2}$

Immunohistochemically pseudovascular ASCC is uniformly reactive with antibodies to cytokeratin, epithelial membrane antigen (EMA), vimentin and blood group antigen. ${ }^{6}$ Immunohistology may prove helpful in the differential diagnosis between ASCC and primary or metastatic adenocarcinoma of skin as ASCC lacks markers of specialised glandular cells. ${ }^{3}$

The lesion is aggressive in nature and due to this behaviour the intraoral cases may not be identical to those of the skin and lips. Therefore identification and correct diagnosis of the lesion is very important for planning the adequate treatment. $^{2}$

\section{CASE REPORT}

Case 1

A 45 year old male patient reported to the private clinic on March $13^{\text {th }}$ 2010, Mangalore, India, with a chief complaint of painless growth in left side of floor of the mouth of three 


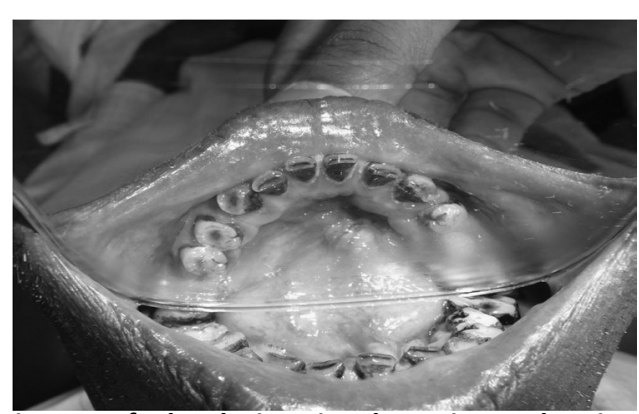

Fig 1. Clinical picture of the lesion in the mirror showing diffuse endophytic growth in the floor of the mouth with and erythematous irregular surface.

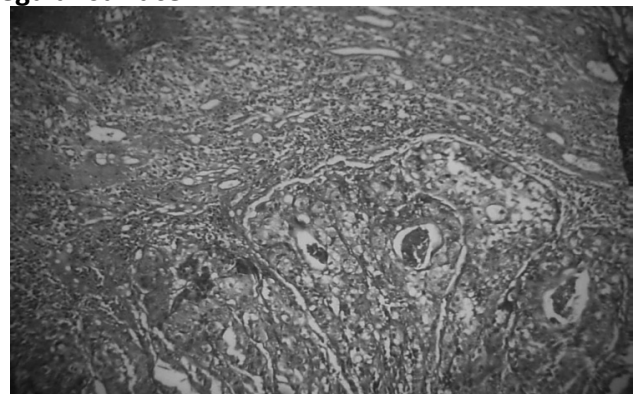

Fig 3. Photomicrograph showing mucous metaplasia of tumor cells.(H \& E, X10).

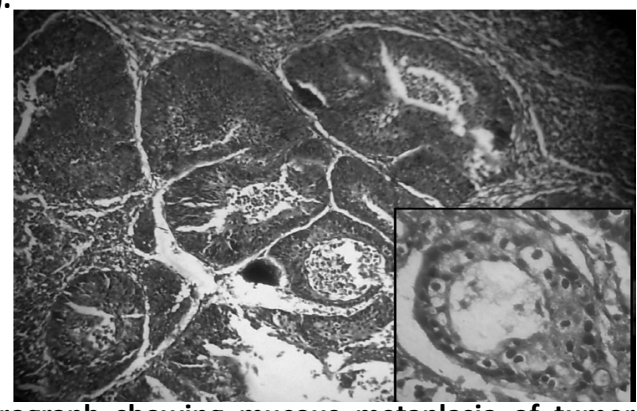

Fig 5. Photomicrograph showing mucous metaplasia of tumor cells and the inset showing pseudoglandular structures containing acantholytic or dyskeratotic epithelial cells (H \& E, X10).

months duration. Personal history revealed that the patient was chronic alcoholic since 15 years and used to smoke six to ten cigarettes/day for past 15 years. Apart from the lesion, the patient appeared clinically healthy. The general condition of the patient was normal and his medical history revealed no significant problem.

On extra oral examination there was no abnormality detected. Intraoral examination revealed a diffuse endophytic growth in the floor of the mouth measuring around $3.5 \times 2.5 \times 2 \mathrm{cms}$. The surface of the swelling appeared irregular. (Fig 1) Some portion of the swelling was erythematous and inflamed. On palpation the swelling was painless, firm in consistency and indurated. It was fixed to the underlying structures. The submandibular lymph nodes were enlarged, painless, movable and firm in consistency.

On the basis of clinical findings and history, a provisional diagnosis of carcinoma was made. Incisional biopsy was performed and was submitted to dept. of Oral Pathology, Yenepoya Dental College, Mangalore for histopathological examination. After fixation in 10 percent formalin solution, the tissue was routinely processed and stained with

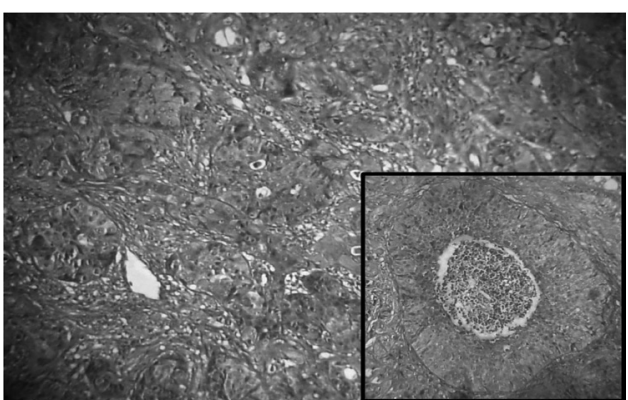

Fig 2. Photomicrograph showing dysplastic epithelial and the inset showing pseudoglandular structures with acantholytic cells in the center of the island. (H \& E, X4 and X40).

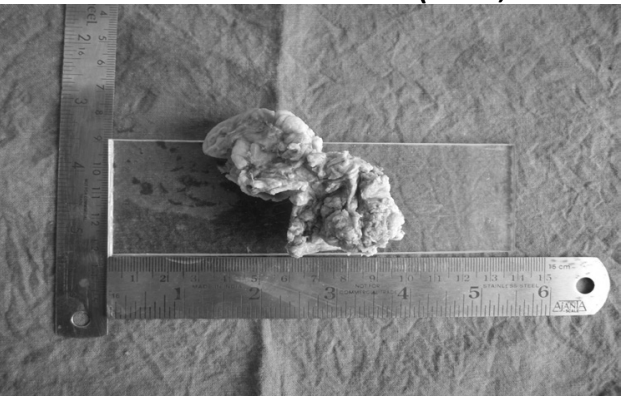

Fig 4. Gross appearance of the lesional tissue of showing wrinkled and corrugated appearance and grevish brown in colour.

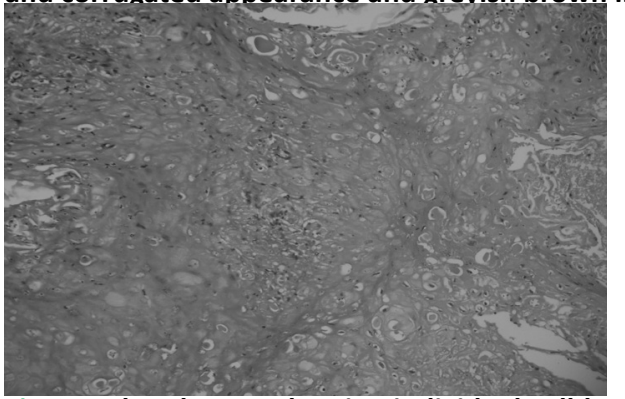

Fig 6. Isolated areas showing individual cell keratinisation with attempted keratin pearls formation. (H \& E, X10).

hematoxylin and eosin.

On microscopic examination, the sections showed lesional tissue with proliferation of highly dysplastic epithelium into connective tissue showing nuclear hyperchromatism, altered nuclear cytoplasmic ratio, numerous normal and abnormal mitotic figures. Individual cell keratinisation was also evident. (Fig 2) Some of the epithelial islands showed tubular ductal structure lined by cuboidal to columnar cells. Pseudoglandular structures contained acantholytic or dyskeratotic epithelial cells (Fig 2 inset). Mucous metaplasia of tumor cells was also evident (Fig 3). Intervening connective tissue was scanty and was diffusely infiltrated with chronic inflammatory cell infiltrate. The overlying stratified squamous epithelium showing dysplastic features is also evident in the lesional tissue. Histochemical staining with Per-iodic acidic Schiff and mucicarmine was done to rule out the possibility of mucoepidermoid carcinoma.

The lesion was very extensive and beyond the scope of surgery, so patient was sent for radiation therapy. At the time of writing, six months after diagnosing, patient had received the total dose of radiation therapy prescribed by 
the radiation oncologist and is under regular follow up.

\section{CASE 2}

A 53 year old male patient reported to the private dentist on March $31^{\text {st }} 2010$, Mangalore, India, with a chief complaint of painless ulcerated lesion on right upper anterior region of two months duration. Personal history revealed that the patient was chronic smoker and smokes, $12-15$ beedies /day for the past 15 years. The general condition of the patient was normal and his medical history was non contributory.

On extra oral examination there was facial asymmetry detected. Intra orally on inspection a linear proliferative growth was observed extending from right lateral incisor to second premolar region. The lesion was measuring $2 \times 5.5$ $x 1.5 \mathrm{~cm}$. On palpation the lesion was firm in consistency, with smooth surface, movable and not fixed. Cervical lymph nodes and other facial areas were normal. To evaluate the bone involvement both paranasal sinus view and orthopantomograph was taken which revealed a hazy radiolucency and destruction of floor of the maxillary sinus.

Based on the clinical findings and history a provisional diagnosis of carcinoma of maxilla/ maxillary sinus was made. Incisional biopsy was performed and was submitted to dept. of Oral Pathology, Yenepoya Dental College, Mangalore for histopathological examination. The gross appearance of the lesional tissue showed wrinkled and corrugated appearance and greyish brown in colour (Fig 4). After fixation in 10 percent formalin solution, the tissue was routinely processed and stained.

On microscopic examination it showed lesional sheets and small islands of dysplastic epithelial cells in connective tissue. The epithelial cells show marked dysplastic features like cellular and nuclear pleomorphism, hyperchromatism, altered nuclear cytoplasmic ratio along with numerous abnormal mitotic figures. Pseudoglandular structures were containing acantholytic or dyskeratotic epithelial cells (Fig 5). Isolated areas of the stratified squamous epithelium in the section showed bizarre squamous cells with individual cell keratinisation and attempted keratin pearl formation (Fig- 6). This gave a definitive clue to come for a final diagnosis of ASCC. Also mucous metaplasias of tumor cells (Fig 5 inset) were evident. The intervening connective tissue is very minimal exhibiting moderate vascularity and minimal chronic inflammatory cell infiltrate.

Primary tumor was resected along with neck dissection. Histopathological examination of the specimen was done which confirmed the incisional biopsy findings. The tumor was infiltrative and the margins were not free of tumor. Therefore further radiotherapy was advised. Presently the patient is receiving radiotherapy.

\section{DISCUSSION}

Adenoid squamous cell carcinoma refers to a rare variant of squamous cell carcinoma containing pseudoglandular spaces or lumina. ${ }^{7}$ It is a different entity from adenosquamous carcinoma, which is composed of both squamous and glandular structures. ${ }^{8}$ Most often the lesions of ASCC develop in sun exposed areas particularly head and neck regions in persons with fair skin who spends considerable time outside, and rarely in the oral cavity. ${ }^{2,7}$

So far 34 cases of ASCC have been reported in oral cavity in English language literature (including the present two cases), (Table 1) of which 23 cases occurred on the vermilion surface of the upper and lower lip. ${ }^{5,10-20}$ Also an additional anecdotal case of ASCC of lip, was described in $1985 .{ }^{14}$ Only 11 cases were reported in other regions of oral cavity. The details of all the cases reported are explained in the table 1.

Jacoway et al in 1971 reported the first and largest series of oral ASCC. ${ }^{10}$ The histopathologic characteristics of the initial lesion were not mentioned, the subsequent ASCC may represent recurrent tumors. Thereafter in the same year, Tomich and hutton in 1972 reported another three cases involving the lower lip. ${ }^{11}$ No recurrence was reported even after the long term follow up.

In 1974, Weitzner et al reported an additional case of ASCC arising on the lower lip. ${ }^{12}$ The author postulated and represented the first histological description of dysplasia (solar keratosis) with acantholysis in the squamous mucosa Table 1. Previously published examples of Oral Adenoid Squamous Cell Carcinoma.

\begin{tabular}{|c|c|c|c|c|c|c|}
\hline Reference & $\begin{array}{l}\text { No. of } \\
\text { cases }\end{array}$ & $\begin{array}{l}\text { Mean } \\
\text { Age }\end{array}$ & Sex & Location & Size & $\begin{array}{l}\text { Follow } \\
\text { up }\end{array}$ \\
\hline $\begin{array}{l}\text { Jacoway } \\
\text { et al }\end{array}$ & 15 & $\begin{array}{r}56.1 \\
(41- \\
75)\end{array}$ & $\begin{array}{l}13 \mathrm{~F} \\
2 \mathrm{M}\end{array}$ & $\begin{array}{r}\mathrm{LL}(11) \\
\mathrm{UL}(3) \\
\mathrm{NS}\end{array}$ & $0.2-1.8$ & $\begin{array}{r}\operatorname{NED}(13) \\
\operatorname{NS}(2)\end{array}$ \\
\hline $\begin{array}{l}\text { Tomich and } \\
\text { Hutton }\end{array}$ & $\begin{array}{r}2 * * \\
1\end{array}$ & $\begin{array}{l}50 \\
53\end{array}$ & $\begin{array}{l}M \\
M\end{array}$ & $\begin{array}{r}\mathrm{LL}(2) \\
\mathrm{LL}\end{array}$ & $0.2-1.8$ & $\operatorname{NED}(3)$ \\
\hline Weitzner & 1 & 67 & M & $\mathrm{LL}$ & $0.2-1.8$ & NED-DOC \\
\hline Goldman & 1 & 61 & $M$ & PTL & NS & DOD \\
\hline Takagi et al & 2 & $\begin{array}{l}50 \\
56\end{array}$ & $\begin{array}{r}F \\
M\end{array}$ & $\begin{array}{r}\text { MXG } \\
\text { LT }\end{array}$ & NS & $\begin{array}{l}\text { DOD } \\
\text { DOD }\end{array}$ \\
\hline Caya et al & 1 & 50 & $M$ & Lip & & NS \\
\hline Cale et al & 3 & $\begin{array}{r}58,47 \\
42\end{array}$ & $\begin{array}{r}2 \mathrm{M} \\
1 \mathrm{~F}\end{array}$ & $\begin{array}{l}\text { FOM } \\
\text { LL(2) }\end{array}$ & $\begin{array}{r}2 \times 1(2) \\
1 \times 1\end{array}$ & $\begin{array}{r}\text { NED (2) } \\
\text { NS }\end{array}$ \\
\hline $\begin{array}{l}\text { Blackburn } \\
\text { et al }\end{array}$ & 1 & 78 & $\mathrm{~F}$ & UL & $1 \times 1$ & NED \\
\hline Zidar et al & 2 & $*$ & $*$ & $*$ & $*$ & * \\
\hline $\begin{array}{l}\text { Kasafuka } \\
\text { et al }\end{array}$ & 1 & 64 & $\mathrm{~F}$ & FOM & $2 \times 1$ & NS \\
\hline $\begin{array}{l}\text { Papadopou- } \\
\text { loa }\end{array}$ & 1 & 72 & $\mathrm{~F}$ & MR & NS & DOD \\
\hline $\begin{array}{l}\text { Kerawala } \\
\text { et al }\end{array}$ & 1 & 56 & $M$ & LT & $1.6 \times 1.1$ & DOD \\
\hline $\begin{array}{l}\text { Present two } \\
\text { cases }\end{array}$ & 2 & & & & & \\
\hline
\end{tabular}

Abbreviation: LL, lower lip; UL, upper lip; PLT, postero-lateral tongue; $M X G$, maxillary gingiva; $L T$, lateral tongue; MR, maxillary ridge; FOM, floor of mouth; NED, no evidence of the lesion; DOD, dead of disease; DOC, died of other causes; NS, not stated; *, details not available. ** Two lesions on the lower lip 14 months apart 
adjacent to the infiltrating neoplasm. First intra oral case of Adenoid squamous cell carcinoma was reported by Goldman et al in $1977 .{ }^{16}$ Treatment rendered was radiation and surgical excision. Unfortunately, the lesion had recurred and had to treat with chemotherapy. He later developed sepsis and died eight months after the initial diagnosis.

Takagi et al in 1977 reported two cases of ASCC in which both the patients died following local recurrence. ${ }^{17}$ Caya et al in 1985 described an ASCC of 50 year old man on the lip. ${ }^{13}$ Anne Cale et al in 1993 reported three cases of oral ASCC. ${ }^{14}$ All three cases there had no evidence of residual tumor and patient appeared free of disease.

A case of primary ASCC of the upper lip associated with a locoregional metastasis was reported by Blackburn et al in 1999. ${ }^{15}$ Immunoreactivity showed negative for $\mathrm{S} 100$ protein, and strongly positive reactivity to high molecular weight cytokeratin and non reactive to vimentin. Histochemistry was negative for mucin. After complete resection, the patient was followed up long term and showed no signs of regional or distant metastasis five years postoperatively.

Zidar et al in 2006 reported two more cases of pseudovascular ASCC of oral cavity. ${ }^{18}$ Microscopically it presented with acantholysis of tumor cells, with formation of anastomosing spaces and channels mimicking an angiosarcoma. In 2006, Kusafuka et al reported another case. ${ }^{19}$ Immunohistochemically it was positive for pan cytokeratin, high molecular weight keratin, cytokeratin CK $7 / 8$, CK 19, E-cadherin and p53, but negative for vimentin, CK 20 and S100.

Papadopoulou et al in 2006 reported a case of 72 year old woman. ${ }^{5}$ She underwent partial maxillectomy and radiotherapy and 17 months after the treatment she died of uncontrollable recurrence. In 2009, Cyrus kerawala reported a case of 56 year old man. ${ }^{20}$ Patient remained well until five months after radiotherapy. Subsequent CT scan showed extensive soft tissue recurrence and he died of locoregional recurrence nine months after his initial presentation.

In the present cases, 45 year old male developed growth on floor of mouth. The lesion was very extensive and beyond the scope of surgery, so patient was sent for radiation therapy. In second case the painless ulcerated growth on right upper anterior region of two months duration. As the margins of the tumor showed involvement and was not free the patient was sent for radiotherapy.

To summarise (Table 1 ) totally 34 cases of ASCC were reported in oral cavity of which 23 cases occurred on the vermilion surface of the upper and lower lip, three in floor of mouth, three on tongue, two on maxillary gingival, one on maxillary ridge, one on maxillary sinus and one not stated (including the present two cases). Age group ranged from 41 to 78 years with mean age 51.9 years. It showed increased predilection for males, 23 in males and 10 in females. The cases were followed up and 22 showed no evidence of lesion. Five died due to disease status and remaining cases status were not stated.

To conclude ASCC is a variant of squamous cell carcinoma which occurs within the oral cavity infrequently. Lip tumors tend to be recognized early and have a good prognosis if excised entire. Intra oral tumors are diagnosed more at later stage and are found to be aggressive. The review of cases reported in the literature has showed that the prognosis of these lesions is relatively poor when compared to conventional squamous cell carcinoma. Therefore precise histopathological diagnosis can help the clinician to plan accurate treatment for the patients.

\section{REFERENCES}

1. Tftsuo $Y$, Yoshio H, Hideo $Y$, Yoshiari $Y$, Srinichi N. An adenoid squamous carcinoma- forming cell line established from an oral keratinizing squamous cell carcinoma expressing carcinoembryonic antigen. Am J Pathol 1986;124 (3):496-509.

2. Rajendran R, Sivapathasundharam B. Shafer's text book of oral pathology. 5th ed. Elsvier publication: Chapter 2, Benign and Malignant tumors of the oral cavity; 2006 p.167-68.

3. Nappi O. Pettinato $G$ and Wick MR Adenoid (acantholytic) squamous cell carcinoma of the skin. Journal of cutaneous Pathology 1989;16(3):114-121.

4. Sigfird AM, Charles MW, Edgar GH, Winkelmann RK. Adenoid squamous cell carcinoma (Adenoacanthoma of lever) report of seven cases and review. Arch Dermatol 1964;89(4):589-97.

5. Papadopoulou E, Tosios KI, Nikitakis N, Papadogeorgakis N, Skiavounup AA. Acantholytic squamous cell carcinoma of the gingival: report of a case a review of literature. Oral Surg Oral Med Oral Pathol Oral Radiol Endod 2010;109(6):67-71.

6. Nappi O, Wick MR, Pettinato G, Ghiselli RW, Swanson PE. Pseudovascular adenoid squamous cell carcinoma of the skin. A neoplasm that may be mistaken for angiosarcoma. The American Journal of Surgical Pathology 1992;16(5):429-38.

7. Zaatari GS, Santoianni RA. Adenoid squamous cell carcinoma of the nasopharynx and neck region. Arch Pathol Lab Med 1986;119(6):54246.

8. Cawson RA, Binnie WH, Speight PM, Barrett AW, Wright JM. Lucas`s Pathology of tumors of the oral tissues. 5th ed. Churchill livingstone Chapter 34, Uncommon types of Carcinoma; 1998. p. 246.

9. Waine CJ, Elson BH. Adenoid squamous cell carcinoma (adenoacanthoma): a clinicopathologic study of 155 patients. Cancer 1966;19(11):1639-50.

10. Jacoway JR, John FN, Robert CB. Adenoid aquamous cell carcinoma (adenoacanthoma) of the oral labial mucosa. A clinicopathological study of fifteen cases. Oral Surg Oral Med Oral Pathol 1971;32(3):44449.

11. Tomich CE, Hutton CE. Ademoid squamous cell carcinoma of the lip: Report of cases. J Oral Surg 1972;30:592-98.

12. Weitzner S, Albuquerque NM. Adenoid squamous cell carcinoma of vermilion mucosa of lower lip. Oral Surg Oral Med Oral Pathol 1974;37(4):589-93.

13. Caya JG, Hidayat AA, Weiner JM. A clinicopathological study of 21 cases of adenoid squamous cell carcinoma of the eyelid and periorbital region. Am J Ophthalmol 1985;99:291. 
14. Cale AJ, Paul DF, Stanley MK. Oral adenoid squamous cell carcinoma: A report of three cases and review of literature. J Oral Maxillofac Surg 1993;51:676-81.

15. Blackburn TK, David M, Brian C. Primary adenoid squamous cell carcinoma of the upper lip associated with a locoregional metastasis: A case report and review and literature. J Oral Maxillofac Surg 1999;57:612-16.

16. Goldman RL, Harvey ZK , Maryana S. Adenoid squamous cell carcinoma of the oral cavity. Report of the first case arising in the tongue. Arch Otolaryngol 1977;103(8):496-98.

17. Takagi M, Sakota Y, Takayama S, Ishikawa G. Adenoid squamous cell carcinoma of the oral mucosa: report of two autopsy casers. Cancer 1977;40(5):2250-55.
18. Zidar N, Cale N, Zupeca A, Dovsak D. Pseudovascular adenoid squamous cell carcinoma of the oral cavity- a report of two cases. $J$ Clin Pathol 2006;59(11):1206-08

19. Kasafuka K, Ebihara M, Ishiki H, Takizawa $Y$, Lida $Y$, Onitsuka T et al. Primary adenoid squamous cell carcinoma of the oral cavity. Pathology International 2006;56(2):78-83

20. Cyrus JK. Acantholytic squamous cell carcinoma of the oral cavity: a more aggressive entity. British Journal of Oral and Maxillofacial Surgery 2009;47:123-125. 